\title{
Assessment of online education problems during the COVID-19 pandemic in Russia
}

\author{
Ilshat Garafiev, Gulshat Garafieva, Angelika Idiatullina, Elena Spirchagova \\ Institute of Innovation Management, Kazan National Research Technological University, Russia
}

\begin{tabular}{l}
\hline Article Info \\
\hline Article history: \\
Received May 4, 2021 \\
Revised Jul 10, 2021 \\
Accepted Jul 18, 2021 \\
\hline
\end{tabular}

Keywords:

COVID-19 pandemic

Human-computer interaction

Learning management system

Networking technology

Online education

\begin{abstract}
The work studied the assessment of online education problems during the COVID-19 pandemic by the first year master's students. It was hypothesized that there are two types of problems. The first type is the problems associated with the difficulties of online communication between the participants of the educational process. The second type is the problems associated with the technical difficulties of participating in online education. The results of factor analysis show that masters clearly distinguish between the content-related (online communication) and formal (technical problems) sides of the organization of online education. It was found that those masters' students who do not work now or do not have work experience in the specialty for which they are studying generally perceive the presence of technical problems and Internet disruptions as difficulties in implementing online education more significantly.
\end{abstract}

This is an open access article under the CC BY-SA license.

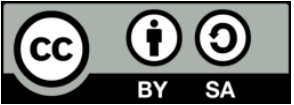

\author{
Corresponding Author: \\ Ilshat Garafiev \\ Institute of Innovation Management \\ Kazan National Research Technological University \\ 68 Karl Marx street, Kazan, Republic of Tatarstan, 420015, Russian Federation \\ Email: ilshatgarafiev@kstu.ru
}

\section{INTRODUCTION}

The first wave of the pandemic caused by the spread of the COVID-19 virus changed the essence of the educational process around the world. Due to the lockdown, universities were forced to switch to online education in the spring semester of the 2019-2020 academic year. During the period of forced online education, teachers, students and representatives of university administration have developed a certain vision of how this type should be implemented. In many countries, the second wave of the pandemic coincided with the beginning of the fall semester of the 2020-2021 academic year. Often lockdowns were introduced not on a national scale, but only in certain regions. This duality also manifested itself in Russia, where from the fall of 2020 in Moscow, St. Petersburg and a number of other cities, students completely switched to online learning, while in some cities, traditional learning with elements of online learning has been preserved. In the cities of the second type, which included Kazan, part of the classes, which were attended by a small number of students, were held on the campus. Usually they were practical classes and work in the laboratory. And part of the classes, where several study groups were to be present at the same time (usually lectures and some seminars), was switched into an online format. As a result, students had a kind of blended learning format.

First-year master's students represent a separate, specific group of Russian student youth. The Russian concept of master's degree as a second level of higher education includes not only its understanding as a kind of pre-postgraduate program, but also as a way to obtain a higher level qualification, which allows one to move up the career ladder. That is why many Russian masters combine study with work or have had experience in the field in which they are studying for a master's degree. They often have a break of several 
years between studying for a bachelor's and master's degrees. Consequently, among the masters of the first year of study, there are those who were not students at the time when all Russian students switched to online education due to the first wave of the pandemic caused by the spread of the COVID-19 virus. This, as well as the presence of a blended learning format, makes it particularly relevant to study the opinion of masters on the problems of online education.

The introduction of elements of online learning into the higher education system was initially associated with the need to determine whether students had the technical ability to learn online[1]. The first studies were conducted in countries with a high standard of living and, as a consequence, with the availability of modern gadgets-Australia [2], [3], the USA [4], and the United Kingdom [5]. These works confirmed the thesis about the technical accessibility of online education. Most of the students had their own devices with Internet access, such as personal computers, tablets and mobile phones, which they used for online communication [6].

The development of modern information and communication technologies [7] has led to an increase in the availability of online education. The issue of the availability of technical capabilities is no longer relevant, since the availability of digital devices with Internet access is becoming a prerequisite for obtaining higher education. Students use information technologies in informal online education, they are ready to apply them in formal education if teachers organize the educational process [8]. The introduction of e-learning expands the access of teachers and students to information and provides a rich environment for collaboration between students [9], e-learning tools are used to interact between students and teachers [10].

The following are distinguished as components of e-learning: technology, delivery systems, communication, and educational paradigms [11]. There are three components of e-learning: curriculum, digital library, ways of presenting knowledge, and it is necessary to integrate synchronous and asynchronous e-learning tools [12]. E-learning is seen as potentially better than traditional because it is cheaper and takes less time [13]. E-learning in higher education is interpreted as the use of information and communication technologies (ICT) for teaching and learning [14]. There is a well-established thesis about the importance of using mixed hybrid forms of education [15], about the positive impact of e-learning on students' abilities and knowledge content [16]. New trends in e-learning include blended learning, personalized learning, massive open online courses [17]. For students, online courses were less valuable than on-campus courses [18], and the perception of face-toface learning was higher than online learning in terms of social presence, social interaction and satisfaction [19].

It is necessary to highlight the works in which the problems and difficulties of introducing elements of online education into the process of traditional education are studied. The blended learning format is interpreted as the integration of interactive elements of online learning into classes conducted in the university classroom, contributing to both independent work of students and joint discussion of the training course materials. From such courses, which are designed, planned and implemented through a combination of physical and virtual learning activities, students get more satisfaction [20], [21], they have increased motivation, engagement and academic performance.

A number of papers have studied attitudes towards the Moodle e-learning system. It is mainly used as a repository of materials. Students emphasize the importance of using the functions of this platform to facilitate the success of the teaching and learning process [21]. Moodle, as an e-learning tool, is used to motivate students and engage them in individual and collaborative homework assignments [22]. Students are not fully aware of the capabilities of moodle, they are ready to use it in order to facilitate the learning process and want the teaching staff to encourage them to use the system [23]. The quality of information is the most significant predictor of student satisfaction when studying the Moodle system [24].

Students rated their online learning experience as positive. Therefore, institutions need to satisfy their students' desire for more flexible, technology-driven learning platforms [25]. Students' high assessment of the effectiveness of e-learning as a lecture preparation tool suggests that the creation of online components contributes to the creation of well-structured courses, which can help to minimize student passivity (lochner) [26].

Students believe that e-learning has a positive effect on learning efficiency [27], on student learning, most teachers have used e-learning as a presentation and preparation tool for classes [28], it improves their academic performance [29]. Knowledge sharing and the quality of university training have a positive effect on student acceptance of e-learning [30].

E-learning is rated by students as a tool that promotes self-discipline, motivation to learn, and interaction with each other and with teachers [31]. The effectiveness of online teaching depends on the degree of use of active pedagogical methods: video conferencing, weekly reflective essays [32]. In e-learning, it is important to use online feedback with the teacher, online discussion of the content of training sessions between students [33]. Students who chose a large number of online courses instead of the traditional ones were less active in coeducation, interacting with students and teachers, and discussing with other people. Universities should take into account that the online environment affects different types of individuals in different ways [34]. Students highlighted the strengths of online education - the possibility of self-study and online interaction with other students, and the weaknesses - the delay in feedback from teachers and the content repository [35]. The 
COVID-19 pandemic has created new challenges for the higher education system in terms of organizing online learning. A survey of university rectors conducted by Inside Higher Ed [36] analyst firm shows that maintaining student engagement is a major challenge for universities in organizing online learning.

International Association of Universities issued a report on the impact of COVID-19 on Higher Education around the world [37]. It should be noted that the role of e-learning in Covid-19 crisis is positive as a pandemic prevention [38]. The forced transition to online education of universities has become one of the reasons for startups, such as EdTech [39]. The normalization of emergency e-learning can increase access to higher education for people who have traditionally been unable to study full-time due to personal or financial circumstances [40]. COVID-19 pandemic has demonstrated the need for integrated learning using ICTs, the success of which depends on technical accessibility, teacher readiness, and student motivation [41].

Students support the implementation of online learning in higher institutions of education as a COVID-19 prevention measure, but students from developing countries have very slow and expensive internet [42]. The negative consequences of the transition to online learning in developed countries are caused by the technical difficulties of students' access to the Internet, which leads to the impossibility of full interaction with the teacher [43]. It is important to use social networks during the COVID-19 pandemic as the only and official tools for academic communication if universities from developing countries do not have formal online learning management systems [44]. The key role in the effectiveness of online learning during the COVID 19 Pandemic period is not played by the availability of training materials for students, but their motivation, the possibility of their interaction with the teacher, who, after receiving real-time feedback, can change their training courses [45]. As educational strategies for online teaching in higher education during the COVID-19 pandemic, the need to design online education taking into account the requirements of traditional university education is highlighted [46], as well as adequate support provided to students by teachers [46] and interactive question sessions to stimulate student engagement [47].

A survey of the opinion of Indian students on online education during the COVID-19 pandemic assumed the respondents' assessment of several groups of indicators: content delivery, interaction, assessment, health issues, social issues[48]. Chinese students highlighted such difficulties of online learning as the need for greater self-discipline and concentration, unstable network speed, lack of professional equipment. The best option in their opinion is to combine recorded videos and live courses with more active online interaction [47].

Among the difficulties that Ukrainian students faced with online education during the COVID-19 pandemic, there were the lack of technical means (modern gadgets and high-speed Internet access), student personal qualities (computer skills and motivation), problems of organizing the educational process (a significant amount of tasks, insufficient control by teachers, unclear teachers' instructions) [49]. The interaction and productivity issues, infrastructure and technical problems were highlighted when examining the online education difficulties faced by Turkish students [50].

In the Russian Federation, a massive sociological survey of students' opinions on the features of online education during the COVID-19 pandemic was conducted. First round (March 24 - April 1, 2020) - 10 938 respondents, second round (May-June 2020) - 24428 respondents. Both rounds of polls were conducted online, and the link to the questionnaire was spread in two ways: selection through the VKontakte social network and through the management of Russian universities. Within the framework of this study, 13 problems of online education were identified. Students were asked to agree or disagree with the presence of one or another problem of online education [51]. The survey results showed that these problems really exist among Russian students. Therefore, we use them as a theoretical basis for our research. We did not change the formulation of the problems, but we changed the tools for their assessment and used the 5-point Likert scale (1 - strongly disagree, 5 - strongly agree). We considered that these 13 problems reflect two types of problems. The first type is the problems associated with the difficulties of online communication between the participants of the educational process, the second type is the problems associated with the technical difficulties of participating in online education.

The aim of the study is to identify the opinion of masters of the first year of study on the problems of online education during the COVID-19 pandemic. The purpose of the study involves the formulation of the following research questions:

1. What is the typology of the problems of online education during the COVID-19 pandemic? Is our hypothesis about the presence of two types of problems: technical problems and problems of online communication correct?

2. What is the close relationship between the significance of online education problems during the COVID19 pandemic?

3. Does the significance of some problem of online education during the COVID-19 pandemic differ among different groups of masters, allocated on the basis of professional experience in the specialty? 


\section{RESEARCH METHOD}

The study was carried out at the Kazan National Research Technological University (faculty of nanomaterials and nanotechnologies, faculty of power engineering and technological equipment) in January 2021, after the end of the 1st semester of the master's program in the following areas of training: Mathematical support and administration of information systems, Food from plant materials, food of animal origin, Product technology and organization of public catering, Materials science and technology of materials, Nanoengineering, Technology of logging and wood processing industries. We conducted a case study to determine the relationship between the assessment of the value of various study skills of masters in natural sciences.

We interviewed $81 \%$ of the total number of students $(\mathrm{N}=100)$ enrolled in these master's programs, but two questionnaires were rejected due to the fact that the respondents did not honestly answer them, choosing the same answer options for all the questions. In total, 79 questionnaires were analyzed. The sample of the study consisted of 79 questionnaires, of which 43 people (54.4\%) were women and 36 people (45.6\%) were men, 72 masters $(91.1 \%)$ graduated from a bachelor's degree or a specialty in natural and technical sciences, 6 people $(7.6 \%)$ - in the field of economics and management, 1 person $(1.3 \%)$ in the field of social sciences and humanities. The survey was conducted in anonymous form, respondents were warned that all results will be used only in a generalized form. The online survey was conducted on the basis of the https://sociotrix.com/ platform. The questionnaire consisted of two parts: general and conceptual. The general part of the questionnaire consisted of questions about the previous experience of studying for a bachelor's or specialist's degree, the year of admission to the master's program, the field of the respondent, and his professional experience.

The conceptual section of the questionnaire included 13 closed questions regarding problem online education during the COVID-19 pandemic. All questions were formulated in the form of statements that the master student had to evaluate on the 5-point Likert scale (1-strongly disagree, 5-strongly agree). Comparison of the answers to these questions was carried out both for the sample as a whole and for various dichotomous groups of students allocated on the basis of the professional experience.

The Cronbach alfa reliability test was used to determine the internal consistency of the questions in the conceptual section of the questionnaire. The descriptive statistics was used in order to analyze the mean of respondents' answer $(1 \leq \mathrm{M} \leq 5)$, standard deviation, mode and median. Principal components analysis was used as a selection method. The Varimax rotation method was also used. Factor analysis was carried out to determine the types of problems that students faced during their online education. To identify the relationship between the various difficulties encountered in the online education format, a correlation analysis was carried out based on the Spearman's correlation coefficient. To compare the mean values of two independent samples, the Mann-Whitney U-test, Jonckheere-Terpstra test, and Kruskal-Wallis test were used. The obtained data were processed in the SPSS-statistics program.

\section{RESULTS AND DISCUSSION}

The Cronbach's alfa reliability test of the questions of the conceptual part of the questionnaire showed the value $\alpha=0.91$ and is within the high reliability range. The results obtained indicate the presence of internal consistency of the questionnaire questions. Therefore, the data obtained meet the consistency criteria and are applicable to describe the problems that the first year master's students face in online education. Table 1 presents descriptive statistics on issues of online education. In general, it can be noted that the transition to an online education format caused some difficulties for masters.

However, according to the average value, they differ. Conventionally, three groups can be distinguished. The first group (DP1, DP2, DP3, DP10) includes problems in which the average value exceeds 3.5 , all of them have a median of 4 , the mode for DP10 is 5, and for the rest is 4 . The second group (DP4, DP6, DP7, DP11) includes problems in which their average value is in the range from 3.11 to 3.29 , and the mode is 4 for all, the median for DP9 is 3, and for the rest is 4. The third group (DP5, DP8, DP9, DP12, DP13) includes problems in which their average value is less than 2, while the mode for DP5is 4, and for the rest is 1 , and the median for DP5, DP9, DP12 is 3, and for DP8 and DP13 is 2. Factor analysis was carried out to determine the types of online education problems. Total variance explained is presented in Table 2.

From the total variance explained table, we can see that two eigenfunctions have values greater than one. Therefore, only two factors were selected for analysis. The first factor explains $48.506 \%$ of the total variance, the second factor $-10.978 \%$.

The obtained results as shown in Table 3 allow us to say that the first factor includes the following difficulties in online education: DP1 (0.654), DP2 (0.877), DP3 (0.725), DP4 (0.684), DP5 (0.717), DP6 (0.654), DP7 (0.781), DP8 (0.638). The second factor includes the following difficulties in online education: DP9 (0.753), DP10 (0.519), DP11 (0.812), DP12 (0.661), DP13 (0.697).

Two indicators were chosen as the criteria on the basis of which the total sample was divided into two independent samples. The first indicator is the combination of master's degree studies with work in a relevant 
specialty. Therefore, two groups of students are distinguished: those who are now working in a relevant specialty and those who are not currently working in it. The basis for identifying these groups was the answer to the question: "Do you have a job in the profile of the program in which you are studying?". The second indicator is the presence of work experience in the specialty for which the respondent is studying in the master's program. Therefore, two groups of students are distinguished: those who have experience in a relevant specialty and those who have no such experience. The basis for identifying these groups was the answer to the question: "Have you ever had a job in the profile of the program in which you are studying?" Based on the fact that the sample size was limited, nonparametric tests were used to compare the mean values of two independent samples: Mann-Whitney U-test, Jonckheere-Terpstra test, Kruskal-Wallis test as shown in Table 4.

Table 1. Descriptive statistics $(\mathrm{N}=79)$ of issues on problems of masters' education in the online format

\begin{tabular}{|c|c|c|c|c|c|}
\hline & Code & Mean & Median & Mode & SD \\
\hline DP1 & Not enough time to communicate with classmates & 3.52 & 4 & 4 & 1.395 \\
\hline $\mathrm{DP} 2$ & Lack of face-to-face discussions with teachers & 3.76 & 4 & 4 & 1.283 \\
\hline DP4 & $\begin{array}{l}\text { It is difficult to answer the teacher's questions and clarify the } \\
\text { issues in the online format }\end{array}$ & 3.29 & 4 & 4 & 1.397 \\
\hline DP7 & Difficulty focusing on self-study & 3.29 & 4 & 4 & 1.407 \\
\hline DP8 & Feeling more lonely, isolated & 2.54 & 2 & 1 & 1.483 \\
\hline DP9 & It is difficult to find a convenient place for online classes & 2.9 & 3 & 1 & 1.481 \\
\hline DP10 & I am experiencing technical problems and internet interruptions & 3.86 & 4 & 5 & 1.227 \\
\hline DP11 & I get embarrassed when the teacher asks to turn on the webcam & 3.13 & 3 & 4 & 1.462 \\
\hline DP12 & $\begin{array}{l}\text { It is difficult to understand the interface of online courses and } \\
\text { programs for online education }\end{array}$ & 2.7 & 3 & 1 & 1.371 \\
\hline
\end{tabular}

Table 2. Total variance explained

\begin{tabular}{lrrrrr}
\hline & \multicolumn{3}{c}{ Initial Eigenvalues } & \multicolumn{2}{c}{ Rotation Sums of Squared Loadings } \\
Component & Total & \% of Variance & Cumulative \% & Total Variance & Cumulative \% \\
\hline 1 & 6.306 & 48.506 & 48.506 & 4.478 & 34.446 \\
2 & 1.427 & 10.978 & 59.484 & 3.255 & 25.037 \\
3 & .975 & 7.498 & 66.981 & & 59.484 \\
4 & .863 & 6.636 & 73.617 & \\
5 & .777 & 5.976 & 79.593 & \\
6 & .534 & 4.108 & 83.701 & \\
7 & .473 & 3.637 & 87.338 & \\
8 & .384 & 2.952 & 90.290 & \\
9 & .348 & 2.676 & 92.966 & \\
10 & .289 & 2.222 & 95.188 & \\
11 & .225 & 1.733 & 96.922 & \\
12 & .209 & 1.606 & 98.528 & \\
13 & .191 & 1.472 & 100.000 & \\
Extraction Method: Principal Component Analysis. & & & \\
\hline
\end{tabular}

Table 3. Rotated component matrixa

\begin{tabular}{lrr}
\hline \multicolumn{1}{c}{ Code } & Component & \multicolumn{2}{c}{} \\
\hline DP1 communication with students & 1 & .152 \\
DP2 communication with the teacher & .654 & -.029 \\
DP3 hard to ask the teacher & .877 & .295 \\
DP4 difficult to answer teacher & .725 & .376 \\
DP5 discussion with students of the studied subject & .684 & .417 \\
DP6 hard to study at home & .654 & .333 \\
DP7 hard to study on your own & .781 & .308 \\
DP8 feel lonely & .638 & .463 \\
DP9 difficult to find a comfortable place & .298 & .753 \\
DP10 internet problems & .334 & .519 \\
DP11 embarrassed to turn on the webcam & .044 & .223 \\
DP12 hard to figure out the interface & .275 \\
DP13 no suitable gadgets & .275 \\
Extraction Method: Principal Component Analysis. Rotation Method: Varimax with Kaiser Normalization. \\
a. Rotation converged in 3 iterations.
\end{tabular}


Table 4. Issues affecting the studies of group students in test statistics

\begin{tabular}{|c|c|c|c|c|c|}
\hline \multirow{2}{*}{\multicolumn{2}{|c|}{ Test Statistics }} & \multicolumn{2}{|c|}{ Code $^{a}$} & \multicolumn{2}{|c|}{$\operatorname{Code}^{\mathrm{b}}$} \\
\hline & & DP10 & DP11 & DP10 & DP11 \\
\hline Mann-Whitney U-test & Sig. (2- tailed) & 0.038 & 0.002 & 0.019 & 0.001 \\
\hline Jonckheere-Terpstra test & Sig. (2- tailed) & 0.038 & 0.002 & 0.019 & 0.001 \\
\hline Kruskal-Wallis Test & Sig. (2- tailed) & 0.038 & 0.002 & 0.019 & 0.001 \\
\hline
\end{tabular}

We see that the results of all three nonparametric tests coincided (Mann-Whitney U-test, Jonckheere-Terpstra test, Kruskal-Wallis Test) for two independent samples according to the criterion "Work in the specialty": for the variable DP10 $\mathrm{p}=0.038$, for the variable DP11p=0.002. According to the criterion "Work experience in the specialty": for the variable DP10 $\mathrm{p}=0.019$, for the variable DP11 $\mathrm{p}=0.001$. The correlation matrix of the indicators presented in Table 1 is presented in Table 5.

Table 5. Spearman's rho correlation matrix of issues on mutual influence of online education problems

\begin{tabular}{|c|c|c|c|c|c|c|c|c|c|c|c|c|c|}
\hline & $\overline{\mathrm{o}}$ & $\stackrel{\tilde{\Lambda}}{\hat{\imath}}$ & $\hat{\tilde{\rho}}$ & 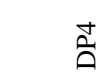 & $\stackrel{n}{n}$ & คे & $\hat{\hat{\imath}}$ & 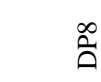 & ڤे & $\begin{array}{l}0 \\
\frac{1}{a}\end{array}$ & $\overrightarrow{\bar{a}}$ & $\frac{N}{a}$ & $\frac{m}{a}$ \\
\hline DP1 & 1 & & & & & & & & & & & & \\
\hline DP2 &, $502 * *$ & 1 & & & & & & & & & & & \\
\hline DP3 & ,468** &, $590 * *$ & 1 & & & & & & & & & & \\
\hline DP4 &, $372 * *$ &, $525 * *$ &, $705 * *$ & 1 & & & & & & & & & \\
\hline DP5 &, $522 * *$ &, $556^{* *}$ &, $560 * *$ &, $619 * *$ & 1 & & & & & & & & \\
\hline DP6 &, $413 * *$ &, $534 * *$ &, $472 * *$ &, $429 * *$ &, $596 * *$ & 1 & & & & & & & \\
\hline DP7 &, $440 * *$ &, $645^{* *}$ &, $670 * *$ &, $562 * *$ &, $651 * *$ &, $654 * *$ & 1 & & & & & & \\
\hline DP8 &, $522 * *$ &, $534 * *$ &, $596 * *$ &, $532 * *$ &, $602 * *$ &, $497 * *$ &, $617 * *$ & 1 & & & & & \\
\hline DP9 &, $348 * *$ &, $313 * *$ &, $450 * *$ &, $445 * *$ &, $476 * *$ &, $507 * *$ &, $501 * *$ &, $503 * *$ & 1 & & & & \\
\hline DP10 &, $364 * *$ &, $223 *$ &, $415 * *$ & ,413** &, $369 * *$ & ,276* &, $317 * *$ &, $544 * *$ &, $286 *$ & 1 & & & \\
\hline DP11 & & &, $310 * *$ &, $349 * *$ &, $320 * *$ &, $389 * *$ &, $319 * *$ &, $363 * *$ &, $622 * *$ & ,419** & 1 & & \\
\hline DP12 &, $284^{*}$ &, $254^{*}$ &, $253^{*}$ &, $425 * *$ &, $525 * *$ &, $344 * *$ &, $336 * *$ &, $446 * *$ &, $468 * *$ &, $339 * *$ &, $315^{* *}$ & & \\
\hline DP13 &, $233^{*}$ &, $255^{*}$ &, $247 *$ & ,481** &, $522 * *$ &, $394 * *$ &, $299 * *$ &, $378 * *$ & ,494** &, $327 * *$ &, $412 * *$ &, $597 * *$ & 1 \\
\hline
\end{tabular}

Here we can observe the interconnection of online education problems with each other. The results of the study show that there are only 76 statistically significant relationships, and if each of the 13 problems is interconnected with all others, 78 of them arise. Of these 76 relationships, 10 relationships can be characterized as very weak, since $r<0.3 ; 37$ can be characterize as weak, since $0.3<r<0.5 ; 28$ relationships can be characterized as medium strength, since $0.5<\mathrm{r}<0.7$; one relationship (DP3-DP4) can be characterized as strong, since $0.7<\mathrm{r}<0.9$. More clearly the relationship of problems is shown in Figure 1.

As can be seen from the data presented in Table 5 and Figure 1, the largest number of statistically significant relationships of average strength in the problem DP7 hard to study on your own (DP7-DP2 $\mathrm{r}=$ 0.645, DP7-DP3 $r=0.670$, DP7-DP5 $r=0.651$, DP7-DP6 $r=0.654$, DP7-DP8 $r=0.617$ ), followed by DP5 discussion with students of the studied subject (DP5-DP4 $\mathrm{r}=0.619$, DP5-DP6 $\mathrm{r}=0.596$, DP5-DP7 $\mathrm{r}=0.651$, DP5-DP8 $\mathrm{r}=0.602$ ).

It should also be noted that most of the problems that made up the second factor do not have medium-strength connections with other problems of distance learning, with the exception of relationships DP9-DP6 $r=0.507$, DP9-DP7 $r=0.501$, DP9- DP8 $r=0.503$, DP9-DP11 $r=0.622$, DP10-DP8 $r=0.544$, DP5-DP12 $r=0.525$, DP5-DP13 $r=0.523$, DP12-DP13 $r=0.597$. 


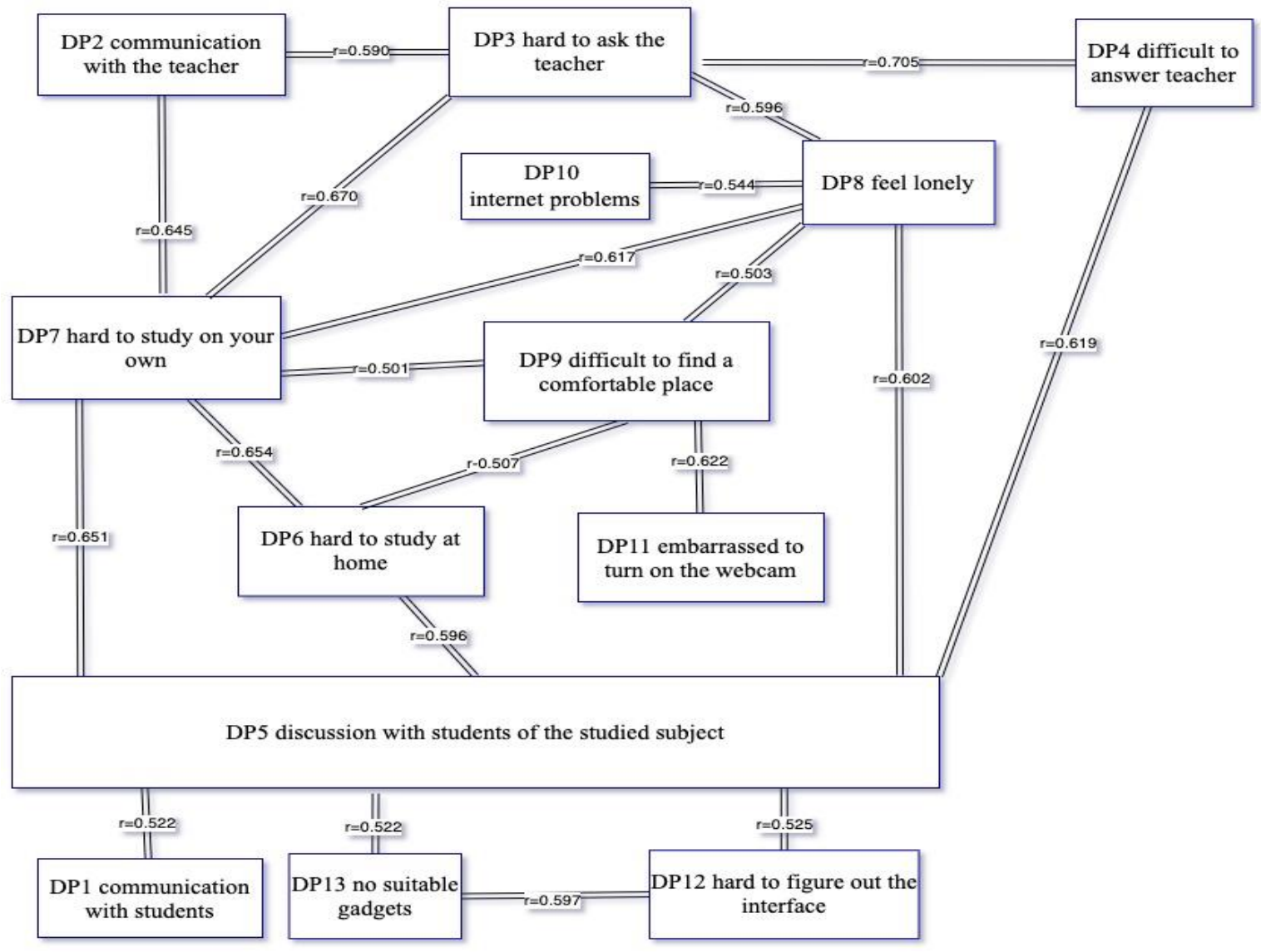

Figure 1. The values of the mutual influence of online education problems

The results of the study allow concluding that the problems of online education during the quarantine period caused by the COVID-19 pandemic were perceived by the masters in different ways. This shows that they had varying degrees of both readiness for online classes and understanding of the inevitability of such a learning format, and, as a consequence, the need to accept it. The least difficulties were caused by the problem of selecting a suitable gadget for learning in an online format, and the greatest difficulties were technical failures and problems with the internet (Table 1). This shows that the general level of computerization among modern masters is quite high. Almost all of them have modern gadgets that allow them to study in an online format, but there are problems with their effective use. Here, the low efficiency of using gadgets for online education can be caused both by the inability to use them correctly and by technical problems that arise for teachers or in the university's online learning system. Internet disruptions could arise as a result of a heavy load on the providers' networks during the lockdown period caused by the COVID-19 pandemic.

The results of factor analysis confirmed our initial hypothesis about the existence of two types of online education problems (Tables 2 and 3). The first type is the problems associated with the difficulties of online communication between the participants of the educational process. The second type is the problems associated with the technical difficulties of participating in distance learning. The current configuration of factors allows us to say that masters clearly distinguish between the content-related (factor no. 1) and formal (factor no. 2) aspects of organizing training in an online format.

We see that those master's students who do not work now or do not have work experience in the specialty for which they are studying generally perceive the presence of technical problems and Internet disruptions more significantly. Among these masters, there are almost no those who would not have difficulty with this problem. This is caused by the fact that people who had work experience are most likely more advanced users of computer programs, since they were constantly using them during the working day in the performance of their professional duties.

It should also be noted that those masters who do not work now or do not have work experience in the specialty for which they are studying generally perceive the problem of communication with the webcam turned on as part of online education more significantly. The embarrassment when turning on the webcam is caused by the fact that the privacy of learning is violated, the students are forced to show their home 
environment to their classmates and the teacher. Maybe the masters working at the moment were partly studying at their workplace, without showing their home environment, if their enterprise was not closed during the lockdown. They could also work from home, be participants in constant online meetings, which usually take place in the format of a video conference with the webcam turned on. So, it turns out that they simply have more experience in business, public, not private online communication.

The obtained correlation model of the relationship between various problems of online education (Table 4, Figure 1) shows that the strongest relationship is between the problems of asking questions to teachers and getting answers to their questions. This is explained by the fact that these problems are perceived by students as two components of the dialogue with teachers, and it is quite logical that the majority of respondents have the same assessment of the difficulties of implementation of the first and second parts of this single process in the online format. Such problems of online education as "hard to study on your own" and "lack of possibility of discussion with students of the studied subject" have most of interconnections of medium strength. These problems are interconnected with each other, and each of them is interconnected with problems such as "hard to study at home" and "feel lonely". This configuration of four problems can be described as the feeling of loneliness that arises when studying independently at home, when there is no opportunity to discuss the material under study with classmates. Also, the problem "hard to study on your own" is still interconnected with such problems as "communication with students" and "hard to ask the teacher", which in fact are the result of the need to study the material independently, without the opportunity to discuss it with the teacher and ask him clarifying questions. Such a problem of online education as "the impossibility of discussing with students of the studied subject" is interconnected at a higher than average level with such a problem as "difficult to answer teacher". It can be assumed that some students, not having the opportunity to clarify the material under study with classmates, cannot answer the teacher's questions. In the event that the training took place in the usual format, such students could find out from their classmates the answers to the expected questions of the teacher before he asks them, for example, at the break. In online education, there is no collective communication between classes.

There is an above-average relationship between "difficult to find a comfortable place" and "embarrassed to turn on the webcam", which is quite logical. A student who cannot find a convenient place for online learning is likely to be embarrassed to show it. Other problems that fell into the second factor during factor analysis, which we interpret as formal, technical problems of online education have fewer relationships. So, the problem of Internet failures and technical problems is interconnected with the problem of feeling lonely, and the problems "hard to figure out the interface" and "no suitable gadgets" with the problem "discussion with students of the studied subject". This configuration shows us that in the usual format, these technical problems could be solved with the help of classmates.

\section{CONCLUSION}

Online education during the quarantine period caused by the COVID-19 pandemic caused both content-related and formal difficulties for masters. Most of the problems we have identified are perceived by students as real difficulties in the implementation of the educational process while studying at the university. In the future, the study can be continued by increasing the target audience, formulating the content of new problems of online education. This is primarily necessary to understand the essence of the second factor. It may be necessary to separately formulate the problems of Internet failure and technical problems. It is also possible to ask a question about technical problems that teachers have, how often it interfered with online education, about problems with access to the university website and the student's personal account. This study explains and studies student perceptions of the challenges of online education during the COVID-19 pandemic. The identified interrelationships of online education problems make it possible to formulate complex management decisions to reduce their importance, which will be implemented in the future when organizing the educational process. The study emphasizes that isolation forced universities to urgently switch to online education for students. There can be no return to the previous education system, e-learning will be used in all training courses. The study offers suggestions for future research on the problems of using online technologies in the higher education system.

\section{ACKNOWLEDGEMENTS}

The authors would like to sincerely thank the participants who took part in this study for their enthusiastic efforts. 


\section{REFERENCES}

[1] J. Wu, S. Guo, H. Huang, W. Liu and Y. Xiang, "Information and Communications Technologies for Sustainable Development Goals: State-of-the-Art, Needs and Perspectives," in IEEE Communications Surveys \& Tutorials, vol. 20, no. 3, pp. 2389-2406, thirdquarter 2018, doi: 10.1109/COMST.2018.2812301.

[2] G. Kennedy et al., "Questioning the net generation: A collaborative project in Australian higher education," in $L$. Markauskaite, P. Goodyear \& P. Reimann (Eds) Who's learning? Whose technology? Proceedings of the 23rd Annual Conference of the Australiasian Society for Computers in Learning in Tertiary Education, 2006, pp. 413417. [Online]. Available: https://ro.uow.edu.au/edupapers/614/.

[3] G. E. Kennedy, T. S. Judd, A. Churchward, K. Gray, and K.-L. Krause, "First year students' experiences with technology: Are they really digital natives?," Australasian journal of educational technology, vol. 24, no. 1, 2008, doi: 10.14742/ajet.1233.

[4] R. B. Kvavik, "Convenience, communications, and control: How students use technology," in Educating the net generation, vol. 1, 2005, p. 7.1-7.20. [Online]. Available: https://www.educause.edu/research-andpublications/books/educating-net-generation/convenience-communications-and-control-how-students-use-technology.

[5] H. Green, Celia. Hannon, and Demos, "Their space : education for a digital generation," London: Demos, 2007.

[6] R. Atat, L. Liu, J. Wu, G. Li, C. Ye and Y. Yang, "Big Data Meet Cyber-Physical Systems: A Panoramic Survey," in IEEE Access, vol. 6, pp. 73603-73636, 2018, doi: 10.1109/ACCESS.2018.2878681.

[7] J. Wu, S. Guo, J. Li and D. Zeng, "Big Data Meet Green Challenges: Big Data Toward Green Applications," in IEEE Systems Journal, vol. 10, no. 3, pp. 888-900, Sept. 2016, doi: 10.1109/JSYST.2016.2550530.

[8] A. Popovici and C. Mironov, "Students' perception on using eLearning technologies," Procedia-Social and Behavioral Sciences, vol. 180, pp. 1514-1519, 2015, doi: 10.1016/j.sbspro.2015.02.300.

[9] V. Arkorful and N. Abaidoo, "The role of e-learning, advantages and disadvantages of its adoption in higher education," International Journal of Instructional Technology and Distance Learning, vol. 12, no. 1, pp. 29-42, 2015.

[10] M. Sadeghi, "A shift from classroom to distance learning: Advantages and limitations," International Journal of Research in English Education, vol. 4, no. 1, pp. 80-88, 2019, doi: 10.29252/ijree.4.1.80.

[11] A. Sangrà, D. Vlachopoulos, and N. Cabrera, "Building an inclusive definition of e-learning: An approach to the conceptual framework,"International Review of Research in Open and Distributed Learning, vol. 13, no. 2, pp. 145-159, 2012, doi: 10.19173/irrodl.v13i2.1161.

[12] N. D. Oye, M. Salleh, and N. A. Iahad, "E-learning methodologies and tools," International Journal of Advanced Computer Science and Applications (IJACSA), vol. 3, no. 2, pp. 48-52, 2012, doi: 10.14569/ijacsa.2012.030208.

[13] M. Suresh, V. Priya, and R. Gayathri, "Effect of e-learning on academic performance of undergraduate students," Drug Invention Today, vol. 10, pp. 1797-1800, 2018.

[14] G. S. Babu and K. Sridevi, "'mportance of E-learning in Higher Education: A study," International Journal of Research Culture Society, vol. 2, no. 5, pp. 1-8, 2018.

[15] P. Ananga and I. K. Biney, "Comparing face-to-face and online teaching and learning in higher education," MIER Journal of Educational Studies Trends \& Practices, pp. 165-179, 2017, doi: 10.52634/mier/2017/v7/i2/1415

[16] M. Zare, Rahele S. M. Salari, and V. Mansouri, "The impact of E-learning on university students' academic achievement and creativity," Journal of Technical Education and Training, vol. 8, no. 1, pp. 25-33, 2016, Accessed: May 02, 2021. [Online]. Available: https://publisher.uthm.edu.my/ojs/index.php/JTET/article/view/1152.

[17] Z. Bezovski and S. Poorani, "The evolution of e-learning and new trends," in Information and Knowledge Management, 2016, vol. 6, no. 3, pp. 50-57.

[18] E. Galy, C. Downey, and J. Johnson, "The effect of using e-learning tools in online and campus-based classrooms on student performance," Journal of Information Technology Education: Research, vol. 10, no. 1, pp. 209-230, 2011, doi: $10.28945 / 1503$

[19] S. Bali and M. C. Liu, "Students' perceptions toward online learning and face-to-face learning courses," in Journal of Physics: Conference Series, 2018, vol. 1108, no. 1, p. 012094. doi: 10.1088/1742-6596/1108/1/012094.

[20] I. Garafiev and G. Gulshat, "Territorial features of value orientations and satisfaction with the studies of student youth in the Republic of Tatarstan," E3S Web of Conferences, vol. 210, p. 18134, 2020, doi: 10.1051/e3sconf/202021018134.

[21] I. Z. Garafiev and G. I. Garafieva, 'The Influence of the Value System in Human Capital Investment on the Satisfaction with Studying at Universities', in Proceeding of the International Science and Technology Conference 'FarEastCon 2020', Singapore, 2021, pp. 1237-1247, doi: 10.1007/978-981-16-0953-4_117.

[22] C. Costa, H. Alvelos, and L. Teixeira, "The use of Moodle e-learning platform: a study in a Portuguese University," Procedia Technology, vol. 5, pp. 334-343, 2012, doi: 1016/j.protcy.2012.09.037.

[23] D. Benta, G. Bologa, and I. Dzitac, "E-learning platforms in higher education. Case study," Procedia Computer Science, vol. 31, pp. 1170-1176, 2014, doi: 10.1016/j.procs.2014.05.373.

[24] G. C. Oproiu, "A Study about Using E-learning Platform (Moodle) in University Teaching Process," Procedia Social and Behavioral Sciences, vol. 180, pp. 426-432, 2015, doi: 10.1016/j.sbspro.2015.02.140.

[25] M. Pérez-Pérez, A. M. Serrano-Bedia, and G. García-Piqueres, "An analysis of factors affecting students' perceptions of learning outcomes with Moodle," Journal of Further and Higher Education, vol. 44, no. 8, pp. 11141129, 2020, doi: 10.1080/0309877X.2019.1664730.

[26] F. M. Alsaaty, E. Carter, D. Abrahams, and F. Alshameri, "Traditional versus online learning in institutions of higher education: Minority business students' perceptions," Business and Management Research, vol. 5, no. 2, pp. 31-41, 2016, doi: 10.5430/bmr.v5n2p31.

[27] L. Lochner, H. Wieser, S. Waldboth, and M. Mischo-Kelling, "Combining traditional anatomy lectures with elearning activities: how do students perceive their learning experience?," International journal of medical education, vol. 7, pp. 69-74, 2016, doi: 10.5116/ijme.56b5.0369. 
[28] K. Odit-Dookhan, "Attitude towards e-learning: The case of mauritian students in public teis," People: International Journal of Social Sciences, vol. 4, no. 3, pp. 628-643, 2018, doi: 10.20319/pijss.2018.43.62864.

[29] M. A. P. Burac, J. M. Fernandez, M. M. A. Cruz, and J. D. Cruz, "Assessing the impact of e-learning system of higher education institution's instructors and students," in IOP Conference Series: Materials Science and Engineering, 2019, vol. 482, no. 1, p. 012009. doi: 10.1088/1757-899x/482/1/012009.

[30] M. V. Mahajan, “A study of students' perception about e-learning," Indian Journal of Clinical Anatomy and Physiology, vol. 5, no. 4, pp. 501-507, 2020, doi: 10.18231/2394-2126.2018.0116.

[31] S. A. Salloum, M. Al-Emran, K. Shaalan, and A. Tarhini, "Factors affecting the E-learning acceptance: A case study from UAE," Education and Information Technologies, vol. 24, no. 1, pp. 509-530, 2019, doi: 10.1007/s10639-018-9786-3.

[32] L. Vitoria, M. Mislinawati, and N. Nurmasyitah, "Students' perceptions on the implementation of e-learning: Helpful or unhelpful?," Journal of Physics: Conference Series, vol. 1088, p. 012058, 2018, doi: 10.1088/17426596/1088/1/012058.

[33] J. Cable and C. Cheung, "Eight principles of effective online teaching: A decade-long lessons learned in project management education," PM World Journal, vol. 6, no. 7, pp. 1-16, 2017.

[34] R. M. Filius, R. A. de Kleijn, S. G. Uijl, F. J. Prins, H. V. van Rijen, and D. E. Grobbee, "Audio peer feedback to promote deep learning in online education," Journal of Computer Assisted Learning, vol. 35, no. 5, pp. 607-619, 2019, doi: 10.1111/jcal.12363.

[35] A. D. Dumford and A. L. Miller, "Online learning in higher education: exploring advantages and disadvantages for engagement," Journal of Computing in Higher Education, vol. 30, no. 3, pp. 452-465, 2018, doi: 10.1007/s12528018-9179-Z.

[36] M. L. C.-Gonzalez, A. M.-Rivilla, M. C. D.-Garrido, and M. M.-Dominguez, "The learning platform in distance higher education: student's perceptions," Turkish Online Journal of Distance Education, vol. 20, no. 1, pp. 71-95, 2019, doi: https://doi.org/10.17718/tojde.522387.

[37] "Responding to the COVID-19 Crisis: A Survey of College and University Presidents," Inside Higher Ed., 2020. [Online].

Available: https://www.insidehighered.com/sites/default/server_files/media/coronavirus\%20presidents\%20survey\%20webcast .pdf

[38] "The Impact of COVID-19 on Higher Education around the World. Retrieved from," International Association of Universities, $2020 . \quad$ [Online]. Available: aiu.net/IMG/pdf/iau_covid19_and_he_survey_report_final_may_2020.pdf.

[39] B. R. Raheem and M. A. Khan, "The role of e-Learning in COVID-19 crisis," International Journal of Creative Research Thought (IJCRT), vol. 8, no. 3, pp. 3135-3138, 2020.

[40] S. Dhawan, "Online learning: A panacea in the time of COVID-19 crisis," Journal of Educational Technology Systems, vol. 49, no. 1, pp. 5-22, 2020, doi: 10.1177/0047239520934018.

[41] M. P. A. Murphy, "COVID-19 and emergency eLearning: Consequences of the securitization of higher education for post-pandemic pedagogy," Contemporary Security Policy, vol. 41, no. 3, pp. 492-505, 2020, doi: $10.1080 / 13523260.2020 .1761749$.

[42] W. Ali, "Online and remote learning in higher education institutes: A necessity in light of COVID-19 pandemic," Higher Education Studies, vol. 10, no. 3, pp. 16-25, 2020, doi: 10.5539/hes.v10n3p16.

[43] J. Demuyakor, "Coronavirus (COVID-19) and online learning in higher institutions of education: A survey of the perceptions of Ghanaian international students in China," Online Journal of Communication and Media Technologies, vol. 10, no. 3, p. e202018, 2020, doi: 10.29333/ojcmt/8286.

[44] M. Adnan and K. Anwar, "Online Learning amid the COVID-19 Pandemic: Students' Perspectives," Online Submission, vol. 2, no. 1, pp. 45-51, 2020, doi: 10.33902/jpsp.2020261309.

[45] A. E. E. Sobaih, A. M. Hasanein, and A. E. Abu Elnasr, "Responses to COVID-19 in Higher Education: Social Media Usage for Sustaining Formal Academic Communication in Developing Countries," Sustainability, vol. 12, no. 16, p. 6520, 2020, doi: 10.3390/su12166520.

[46] D. Popa, A. Repanovici, D. Lupu, M. Norel, and C. Coman, "Using Mixed Methods to Understand Teaching and Learning in COVID 19 Times," Sustainability, vol. 12, no. 20, p. 8726, 2020, doi: 10.3390/su12208726.

[47] W. Bao, "COVID-19 and online teaching in higher education: A case study of Peking University," Human Behavior and Emerging Technologies, vol. 2, no. 2, pp. 113-115, 2020, doi: 10.1002/hbe2.191.

[48] L. Sun, Y. Tang, and W. Zuo, "Coronavirus pushes education online," Nature Materials, vol. 19, no. 6, pp. 687687, 2020, doi: 10.1038/s41563-020-0678-8.

[49] P. Chakraborty, P. Mittal, M. S. Gupta, S. Yadav, and A. Arora, "Opinion of students on online education during the COVID-19 pandemic," Human Behavior and Emerging Technologies, vol. 3, no. 3, pp. 357-365, doi: 10.1002/hbe2.240.

[50] Y. Nenko, N. Kybalna, and Y. Snisarenko, "The COVID-19 Distance Learning: Insight from Ukrainian students," Revista Brasileira de Educação do Campo 5, vol. 5, no. 0, pp. e8925-e8925, 2020, doi: 10.20873/uft.rbec.e8925.

[51] M. T. Hebebci, Y. Bertiz, and S. Alan, "Investigation of views of students and teachers on distance education practices during the Coronavirus (COVID-19) Pandemic," International Journal of Technology in Education and Science (IJTES), vol. 4, no. 4, pp. 267-282, 2020, doi: 10.46328/ijtes.v4i4.113.

[52] "Survey of students of Russian universities on the conditions of distance learning", Institute of Education HSE University. [Online]. https://www.hse.ru/data/2020/08/05/1601412655/Student_COVID_survey_2020.pdf. 